\title{
TAX REASONS FOR ESTABLISHING A HEADQUARTER COMPANY
}

\author{
Thabo Legwaila \\ Bluris LLB LLM PG Dip Tax Law LLM LLD \\ Extra-ordinary Lecturer, University of Pretoria
}

\begin{abstract}
SUMMARY
Headquarter companies are generally interposed between the ultimate holding company and the operating subsidiaries of a group of companies. The functions of a headquarter company are mainly to manage investments and to centralize the income of the group prior to remittance to the ultimate holding company. Therefore, generally, the rationale for setting up a headquarter company is based on economic and structural needs of the group in which the headquarter company is to be set up. However, it is also common cause that the decision to set up a headquarter company is, more often than not, influenced by the need to take advantage of tax instruments available in the particular jurisdiction. This allows the group to reduce its overall tax liability and therefore increase its after tax earnings.
\end{abstract}

\section{$1 \quad$ INTRODUCTION}

In international tax planning, international headquarter companies (hereinafter referred to as "headquarter companies") play a major role in the management of the investors' investments. International headquarter companies are often formed where multinational groups of companies have significant economic interests in a region which is distant from its head office to oversee and coordinate the group's business interests in a particular region. ${ }^{1}$ They are generally interposed between the ultimate holding company and the operating subsidiaries in the group of companies.

"Such centres will usually provide the full range of administrative and management functions associated with a head office; for example, treasury and tax management, internal audit, public relations, market research and marketing, insurance and accounting." "It is, therefore, not infrequent that a group of companies would have multiple headquarter companies, each serving group companies in contiguous countries within a particular region.

In the development of tax systems, countries have shown great interest in attracting investors to inter alia set up headquarter companies within their jurisdictions in order to benefit from the spillover benefits that attach to the presence of headquarter companies. These countries include Belgium, Denmark, Luxembourg, Mauritius, the Netherlands, Singapore and the United Kingdom. South Africa added itself to this list by its announcement in the 2010

Ogley Principles of International Tax: A Multinational Perspective (1993) 137.

Ogley 137. 
Budget Review that it plans to market itself as a gateway to investment into Africa. ${ }^{3}$

\section{BACKGROUND}

Tax planning is one of the main considerations in any investment planning. As Graetz ${ }^{4}$ states, "[a] deal done by very smart people that absent tax considerations, would be stupid". Complementary to this, Lord Tomlin's oftquoted dictum in IRC $v$ Duke of Westminster $r^{5}$ that "[e]very man is entitled if he can to order his affairs so that the tax attaching under the appropriate Acts is less than it otherwise would be", ${ }^{6}$ finds support from or is at least acknowledged by all sectors of business, revenue authorities, government treasury departments and academics as forming the cornerstone of any tax jurisdiction. Russo explains the principle as follows: ${ }^{7}$

"A key determinant of shareholder value under current corporate reporting guidelines is earnings per share (EPS). An important element of EPS or the bottom line is tax. The net effect of having an [effective tax rate ("ETR")] of $35 \%$ to $40 \%$ is that any earnings resulting from organic growth, acquisitions or other corporate initiatives, are diluted by $35 \%$ to $40 \%$. It should thus be clear that ETR, as reported in [a multinational enterprise's] financial statements, significantly impacts EPS and therefore has a direct impact on the shareholder value. In order to have a positive impact on EPS, however, tax savings must be sustainable."

Tax evasion, ${ }^{8}$ avoidance ${ }^{9}$ and minimization ${ }^{10}$ as methods of dealing with one's tax affairs are embarked upon locally as well as internationally. While a headquarter company is not necessarily formed to achieve tax savings, the

National Treasury Budget Review (2010) 78-79.

See Graetz (Yale Law School) as quoted in Hager, Treasury Targets Shelters Again, Washington Post (1999) E3 in relation to tax planning using tax shelters.

[1936] AC 1 at 19, [1935] All ER Rep 259.

267.

Russo Fundamentals of International Tax Planning (2007) 73.

8 Tax evasion, connotes the use of illegal and dishonest means to escape tax, for which penalties are normally prescribed. This can take many forms, from falsification of records to concealment of income or taxable events. See CIR v Conhage (Pty) (Ltd) 19994 SA 1149 (SCA); and CIR v King 19472 SA 196 (A). See also Williams Income Tax in South Africa (2006) 771

9 Tax avoidance is the usage of legal ways to regulate one's affairs in such a way that one pays the minimum tax imposed by law rather than the maximum. Put differently, tax avoidance is the legitimate and legal process of protecting one's property from unnecessary erosion by taxation. See Joubert and Faris (eds) LAWSA 6 (2000) 1 par 632; Tooma Legislating against Tax Avoidance (2008) 12-18.

10 Tax minimization, as opposed to tax avoidance involves no degree of cunning and no structures designed - just an application of the tax laws and interpretation to the particular facts and circumstances in order to pay the right amount of tax payable, with no prejudice suffered. Thus tax minimization does not seek to take advantage of possible contentious loopholes in the tax system (as does tax avoidance) but applies the tax laws to the taxpayer's advantage as much as is possible. As can be seen, the distinction between tax avoidance and tax minimization is very slight. In some interpretations the two overlap to a large extent. See LexisNexis "Objectives of Estate Planning" http://butterworths/nxt/ gateway.dll (accessed 2010-05-25), where it is further stated that " $[\mathrm{t}] \mathrm{he}$ conventional wisdom is that an estate plan should ensure that no income tax prejudice is suffered, but is unlikely to lead to income tax savings. If these do eventuate, well and good, but such savings should be neither promised nor expected". 
decision regarding where it is formed is, to varying degrees, influenced by tax consequences. In this way, the decision to set it up or to locate it within a particular jurisdiction does constitute at least an attempt to reduce the worldwide tax liability.

Often investors set up headquarter companies, or set them up in specific jurisdictions in order to access tax benefits or tax benefits offered by the chosen jurisdiction. These are normally tax benefits which the investor would otherwise not be able to access without the use of the headquarter company or without locating the headquarter company in that particular jurisdiction. What follows is an appraisal of some of the main tax reasons why an investor may choose to form a headquarter company or set it up in a particular jurisdiction. It needs to be noted at the outset that investors would generally be more motivated to form a headquarter company where more than one reason exists - and, still better, where there is a combination of the tax reasons and the non-tax reasons. ${ }^{1}$

\section{DEFERRING TAX ON OPERATING INCOME}

The operating income of a business activity is income produced by the business's operating activities. The International Financial Reporting Standards ("IFRS") define operating activities as the principal revenueproducing activities of an entity and other activities that are not investing or financing activities. ${ }^{12}$ Thus, according to the IFRS, the operating incomes of businesses would differ depending on the specific nature of business of a particular enterprise. ${ }^{13}$ Investing activities mean the acquisition and disposal of long-term assets and other investments not included in cash equivalents. ${ }^{14}$ Thus, the IFRS treatment would include in operating activities liquid investments convertible to cash, including dividends, rental and royalties.

From a tax point of view, operating income is akin to revenue income. Revenue receipt is the income which arises from a business activity or the employment of capital either by using it or by letting it. The classification is, however, subjective.

Investors mainly earn income from their equity investments by way of dividends. Investors may defer tax on operating income by trapping the dividends at the headquarter company level instead of remitting them to the home country. In circumstances where income is taxable or exempt, depending on its source, a headquarter company can be used to channel only

11 Some of the non-tax reasons are supervision and co-ordination of administrative services; group finance facilities; listing; avoidance of exchange controls; and asset protection.

12 IAS 14.8, International Financial Reporting Systems including International Accounting Standards and Interpretations as at 1 January 2006, International Accounting Standards Board, United Kingdom.

13 An apple-farming business would have the income from selling apples as its operating income, just as an audit firm's income would be derived from consulting services. Income from the sale of land would be operating income in the hands of a dealer in land.

14 Cash equivalents are short-term, highly liquid investments that are readily convertible to known amounts of cash and that are subject to an insignificant risk of changes in value. See International Financial Reporting Systems including International Accounting Standards and Interpretations as at 1 January 2006, International Accounting Standards Board IAS 14.8. United Kingdom. 
exempt income back to the investor country. ${ }^{15}$ This would be the case, for example, where there is a participation exemption on certain dividends.

Generally, this form of deferral is affected by the application of controlled foreign companies' (hereinafter referred to as "CFC") legislation in the home countries of the investors. CFC legislation generally attributes income of a foreign company that is substantially held by residents to its resident shareholders in proportion to their shareholding. The primary objective of CFC legislation is to tax residents on income shifted to low-income jurisdictions with no business objective and on income that is trapped in foreign jurisdictions as a result of the foreign company not declaring dividends. CFC legislation achieves this by attributing the income to the resident shareholders of the CFC in the year that the income is earned. ${ }^{16}$

Legislative intervention to achieve these goals is constantly under intense scrutiny by taxpayers, who attempt to circumvent it. One of the ways of doing so is at the planning stages where investors ensure that investors in the home country hold less than the required percentage for the company to be a CFC. In this way, as most dividends would be subject to a participation exemption of, say, $25 \%$, the investor can get the dividends free from withholding taxes and, possibly, without a tax on foreign dividends. ${ }^{17}$

A headquarter company can also be used to defer tax on a CFC's operating income. For example, in Mexico, CFC legislation requires taxpayers to accrue into their Mexican taxable income the gross revenues realized by subsidiaries located or resident in low tax jurisdictions. They are required to accrue into their taxable income revenues derived not only by their first-tier subsidiaries, but also those accrued by lower-tier subsidiaries located in lowtax jurisdictions. Moreover, contrary to the approach taken by other jurisdictions, the Mexican CFC legislation does not grant Mexican taxpayers a deemed paid credit (that is, an indirect credit) for income taxes paid by the low-tax jurisdiction corporation. Taxpayers defer the recognition of the low-tax jurisdiction company's earnings by interposing a headquarter company in a jurisdiction with CFC legislation, provided that the intermediary jurisdiction's CFC legislation is applicable to the intermediary foreign headquarter company. ${ }^{18}$

15 Olivier and Honiball International Tax, A South African Perspective (2008) 302.

16 Foreign companies that are controlled by residents of other countries are often used to keep their income in the foreign jurisdiction by the residents of the other countries by, in the exercise of their controlling powers, prohibiting the foreign company from declaring dividends. This is the reason why CFC legislation seldom subjects the income of non-controlling shareholders to attribution.

17 Interest, royalties and rental treatment as operating income do not fall within the scope of this discussion because companies that have such income as operating income would be financial instruments headquarter companies, intellectual property headquarter companies and rental companies, respectively. These, as discussed before, do not have the essential characteristics of a general headquarter company.

18 See Solano, Alvarez, Fabregat and Santos "Mexico Bill: Tough on Tax Havens" (December 1997/January 1998) International Tax Review http://www.internationaltaxreview.com/ Default.asp?Page=10\&PUBID=35\&ISS $=12666 \& S I D=468530 \& S M=\& S e a r c h S t r=\% 22 i n t e r m e d$ iary\%20holding\%20company\%22 (accessed 2010-06-01). 


\section{DEFERRING TAX ON CAPITAL GAINS}

Both internationally and for South African tax purposes, the distinction between capital and revenue plays an important role in the decision to form and locate a headquarter company. Traditionally, most jurisdictions treat capital gains more favourably than ordinary income. For example, in South Africa the effective capital gains tax ("CGT") rate for companies is half that of the normal income tax rate (due to the inclusion rate). ${ }^{19}$

A capital gain arises on the disposal of a capital asset. The determination of whether an asset is capital in nature (similar to whether an asset is a revenue asset) depends on the intention that the taxpayer has and how the investor deals with the asset. Most countries have a wealth of tax jurisprudence on the distinction between capital and revenue, as capital gains is generally more favourably treated than revenue gains. ${ }^{20}$

Capital assets of a company include the cash given in lieu of the shares and the assets that the company utilizes to produce its income. Shares are capital assets in the hands of the shareholders, unless these shareholders hold such shares as trading stock. However, shares that a company holds in another company are assets in the hands of the former company. Assets that a company uses as capital assets include intellectual property. Intellectual property is one asset the value of which generally increases as the enterprise becomes a successful undertaking. ${ }^{21}$

While tax on operating income is generally triggered by an accrual or a receipt, tax on capital gains is generally triggered by disposal or disposition. Disposal has a very broad definition and captures almost all instances in which an asset is alienated. ${ }^{22}$ The International Bureau of Fiscal Documentation $^{23}$ defines disposal as follows:

"The term is often given a broad meaning and may, depending on the country involved, cover sales, exchanges, gifts or bequests; leasing, surrender or forfeiture; the receipt of insurance moneys or other compensation; the receipt of a sum for exploration of an asset; the receipt of a sum for refraining from exercising rights; the destruction or abandonment of an asset; emigration of the taxpayer; and the transfer of the taxpayer's business property to his private property.

19 See par 10 of the Eighth Schedule to the Act. See also Olivier and Honiball 301; Wilcocks and Strydom "The Concept of 'Disposal' for the Purposes of Capital Gains Tax in South Africa" 2000 Meditari Accountancy Research 312; Davis What You Must Know About Capital Gains Tax (2001) 4; Geach Capital Gains Tax in South Africa - The Essential Guide (2001) 16.

20 See Ault Comperative Income Taxation (1997) 194-195.

21 See Bently and Sherman Intellectual Property Law (2009) 1-11.

22 Haccius Ireland in International Tax Planning (2004) 19; "Capital Gains Tax Guide" http://www.bizland.co.za/cgt.htm\#triggers (accessed 2010-06-15). HM Revenue \& Customs "Capital Gains Tax" http://www.hmrc.gov.uk/cgt/index.htm (accessed on 2010-06-15).

23 IBFD International Tax Glossary definition of "disposal".

24 Paragraph 11 of the Eighth Schedule to the Act. See also Wilcocks and Strydom 2000 Meditari Accountancy Research 312. For South African purposes and subject to certain specific exclusions, a disposal is defined in the Act as follows: a disposal is any event, act, forbearance or operation of law which results in the creation, variation, transfer or extinction of an asset, and includes (a) the sale, donation, expropriation, conversion, grant, cession, exchange or any other alienation or transfer of ownership of an asset; (b) the forfeiture, 
In addition to these and other forms of disposals in different jurisdictions, certain events that are strictly not disposals are deemed as disposals. As Whiteman ${ }^{25}$ observes, "[c]hargeable disposals fall into two categories: those events or transactions which can be regarded as a 'disposal' within the ordinary meaning of that word ... and those events or transactions which are treated as notional 'disposals' though no actual disposal takes place". However, as a general rule a company does not dispose of an asset when it issues shares or when it grants an option to acquire a share or debenture in the company.

Investors would generally prefer to invest in countries with low or no capitalgains tax. However, this is not easy to do, as tax, let alone CGT, cannot be the only motivation for investing in a particular country. With a wide range of activities deemed to be disposals, investors would rather invest in a country where there are fewer disposal events. In this way, although the CGT rate may be high, the CGT base is not broad and certain gains may escape taxation and therefore bring the effective CGT rate down.

Based on the aforegoing, depending on the objectives of the group companies and what assets the companies hold, an investment decision is made on the location, influenced to a large extent by the tax treatment. For example, a group that holds capital assets that are moved from one company to another or a group that envisages restructuring would prefer a jurisdiction that does not deem the movement of assets within the group as a disposal for CGT purposes.

The main problem that most groups experience is that even if CGT is avoided in the host country under a DTA, the home country may still have the right to levy CGT. Thus, where the home country deems a change in residence as a disposal, the CGT on all worldwide assets, subject to DTAs, is triggered. Therefore, the investor would rather move the residence of the company outside of the home country before the company acquires assets or where assets are already acquired, at the earliest stage before the assets appreciate much in value. ${ }^{26}$ Alternatively, it is preferable for assets to be owned by a company located in a jurisdiction where the change of residence would not trigger a disposal, thus necessitating the location of a headquarter company in such a country.

It is preferable that the country in which the investor locates the headquarter company should not tax capital gains on cessation of residence as that would jeopardize the chances of further relocation of residence should that be desired in the future. ${ }^{27}$ Where cessation of residence is not a trigger in

termination, redemption, cancellation, surrender, discharge, relinquishment, release, waiver, renunciation, expiry or abandonment of an asset; (c) the scrapping, loss, or destruction of an asset; (d) the vesting of an interest in an asset of a trust in a beneficiary; (e) the distribution of an asset by a company to a shareholder; (f) the granting, renewal, extension or exercise of an option; or (g) the decrease in value of a person's interest in a company, trust or partnership as a result of a value shifting arrangement. See Geach 30-42; Davis 10-19; and Williams Capital Gains Tax - A Practitioner's Manual (2005) 32.

25 See Whiteman Whiteman and Wheatcroft on Capital Gains Tax (1980) 23.

26 See Olivier and Honiball 301. Also see Ogley Chapter 9.

27 The Netherlands and Mauritius are examples of jurisdictions that do not levy capital-gains tax on cessation of residence. Switzerland does levy capital-gains tax on cessation of residence and as a result the numbers of headquarter companies in that country have declined since 
the investor country, the tax that would have been levied on relocation would be deferred. Even then, some investors prefer to be taxed once when the value of the gain is low and defer the rest of the gain such that they would allow a tax on capital gains on relocation from the home country with anticipation of a large increase in the value of the assets in the short term. Some countries have anti-avoidance measures that are specifically designed and intended to combat this type of avoidance. ${ }^{28}$

\section{MAXIMIZING CREDIT FOR FOREIGN TAXES}

Legislation in most countries allow the tax authorities to grant unilateral tax relief against double taxation by not taxing foreign income or allowing a tax credit on the foreign taxes paid, or deduction or exemption on the income in respect of which foreign taxes were paid, to a foreign government. ${ }^{29}$ Tax treaties also offer such relief but the relief is not general as it is limited to countries which have DTAs with each other. In a discussion that follows, the main elements of these options are examined. The importance of these provisions for headquarter companies is that headquarter companies often receive amounts that have been taxed in the jurisdictions in which such amounts are sourced. These include dividends from their non-resident subsidiaries and capital gains on the sale of capital assets located offshore.

\section{No tax on foreign income}

One of the ways of avoiding double taxation is to apply the source-based tax purely and to tax only income sourced in the country applying the tax. This system is not popular at all as it is prone to tax avoidance and is not in line with the usual international norm of worldwide taxation of residents, rather than taxing on the basis of source. ${ }^{30}$

\section{Foreign tax as an allowable deduction in determining taxable income}

A tax deduction is a mechanism to prevent juridical double taxation. In the deduction system, the tax payable or paid to foreign countries is deducted in the calculation of the taxable income of a resident. This method is used in some countries as a fallback from a foreign-tax credit method where the credit may not be of use to the taxpayers. It is, however, not widely accepted as a

the introduction of the capital-gains tax in that country. South Africa also levies CGT on cessation of residence. See par 12(2)(a) of the Eighth Schedule.

28 The USA is one of the countries that apply anti-avoidance measures in respect of intellectual property. In South Africa the anti-avoidance measure contained in S 231 was introduced in 2007 by the Revenue Laws Amendment Act 35 of 2007.

29 McLure "Must Corporate Income be Taxed Twice?: A Report of a Conference Sponsored by the Fund for Public Policy Research and the Brookings Institution" 1979 Fund for Public Policy Research, Brookings Institution 79; See also "Foreign Tax Credit" http://www. taxalmanac.org/index.php/Foreign_Tax_Credit (accessed 2010-04-14).

30 See Vann Tax Law Design and Drafting (ed Thuronyi) (1998) 756. See also Davis Principles of International Double Taxation Relief (1985) Chapter 5. 
method to be used on its own without being coupled with other methods available. ${ }^{31}$

This method, compared with the others, yields less relief for taxpayers, as all that is deducted is the actual tax payable or paid. The benefit that the taxpayer derives is only the non-taxation of the amount of tax paid or payable. The formula could be represented as follows:

$(A-B) \times C=D$

Where:

$A$ is the taxable income;

$B$ is the tax paid in the foreign country;

$C$ is the local tax rate; and

$\mathrm{D}$ is the tax payable in the home country.

\section{Tax exemption}

The exemption method exempts foreign-sourced income from tax in the home country. Thus, the foreign-sourced income is not included in the calculation of taxable income. Several jurisdictions apply this system subject to certain conditions. ${ }^{32}$ Mainly the conditions relate to the fact that the income has actually been taxed (as opposed to tax that is payable or that the income is subject to tax) in the foreign country. Some systems place conditions on actual tax rates while others exempt income sourced in certain countries. ${ }^{33}$

Certain exemptions are blatantly conditional, for example exemption on receipts and accruals of foreign ship or aircraft owners or aircraft or charterers if a similar exemption or equivalent relief is granted to the taxing country's residents by the country in which that person is resident. ${ }^{34}$ In this regard Vann ${ }^{35}$ states:

"If the exemption is unconditional and the exemption does not affect in any way the taxation of other income, then in substance the result is the same as a purely territorial system. Most countries using an exemption system adopt exemption with progression, under which the total tax on all income of a resident is calculated, and then the average rate of tax is applied to the income that does not enjoy the exemption."

Countries that apply the exemption method apply it only to certain specified items of income. ${ }^{36}$

Where income is exempt, the expenditure incurred in producing that income is generally not deductible in the hands of the resident. For example,

31 See Vann 757; and Olivier and Honiball 315.

32 Arnold and McIntyre International Tax Primer (2002) 33-34.

33 South Africa, by the mechanism of $\mathrm{S} 9 \mathrm{D}(9)$ (a) of the Act exempted from the CFC attribution, income of a CFC located in "designated countries." This provision has since been repealed by $s 22(1)$ of Act 45 of 2003.

34 For the South African equivalent provision, see s 10(1)(cG) of the Act.

35 Vann 757.

$36 \mathrm{Eg}$, South Africa applies the exemption method to certain foreign dividends (s10(1)(k)(ii)), income received by crew members of ships operating outside the South African territorial waters $(\mathrm{s} 10(1)(0))$ and royalties $(\mathrm{s} 10(1)(\mathrm{m}))$. 
in South Africa when the source-based system of tax was applicable, income from a non-South African source was not taxable in South Africa. Therefore, the interest incurred in producing that income was not deductible in South Africa. The same applies with foreign dividends. The interest incurred in producing exempt foreign dividends is not deductible while the interest incurred in producing taxable foreign dividends is deductible, but limited to the amount of the dividends.

\section{Tax credits}

This is the most popular form of unilateral double-tax avoidance. This system gives a credit against total tax on worldwide income for foreign taxes paid or payable on foreign income by a resident. ${ }^{37}$ In this system, the credit is given against the tax payable in the host country. Thus, while in the deduction method the deduction is given when determining the taxable income, the credit system gives the credit against the actual tax paid or payable. ${ }^{38}$ The calculation starts by determining the taxable income and then the tax payable. Once the tax payable is determined, the tax paid in the foreign countries is deducted. The formula can be represented as follows:

$A-B=C$

Where:

A is the tax payable before the credit is applied;

$B$ is the tax paid in the foreign countries; and

$\mathrm{C}$ is the final tax payable.

This is therefore the most effective and practical unilateral method of avoiding double taxation in that the taxpayer's tax is effectively limited to the higher of the tax of either jurisdiction. The credit is normally limited to the tax payable in the host country. As Vann ${ }^{39}$ states, "[t]his limit is designed to ensure that foreign taxes do not reduce the tax on domestic income of residents and is calculated by applying the average rate of tax on the worldwide income before the credit to the foreign-source income."

In South Africa a tax rebate applies in relation to the following: ${ }^{40}$

- Revenue income or capital gain received by or accrued to a resident from any source outside South Africa which is not deemed to be from a South African source;

- Any proportional amount of income in terms of the CFC rules;

- Any foreign dividend;

- Any revenue income or capital gain deemed to have been accrued to a resident in terms of tax-back provisions in the Act.

37 Arnold and McIntyre 36. See also "Taxes: what is the foreign tax credit?" http://www.essortment.com/home/taxesforeignta_smsr.htm (accessed 13 April 2010).

38 Russo 10.

39 Vann 757.

40 See $s$ 6quat(1) of the Act. 
The exemption method generally provides the best benefits for the taxpayers. However, where the tax rate in the source country is higher, the credit method provides equal relief to the exemption method. The use of these methods either on their own or in combination with the other methods is very effective for the elimination of double taxation. With the deduction method, one can only receive a credit where there has been a tax loss. Even then, tax systems generally ring-fence tax losses. As a result one would not be able to utilize the tax loss from a foreign country in one's home country.

\section{REDUCING WITHHOLDING TAXES}

Withholding tax is not a tax as such, but rather a method of tax collection employed by tax administrations to ensure payment of tax. ${ }^{41}$ Before withholding can be applied, there has to be an underlying tax liability on the part of the taxpayer. The tax may be a tax on royalties, dividend tax, or even income tax. The terminology often extends to coupling the nature of the tax with the element of withholding like "a withholding tax on royalties". ${ }^{42}$

The obligation to withhold is on the person making the payment. Generally, the person receiving the amount has no right of recourse whatsoever against the person withholding the amount in respect of the amount legally withheld. However, a contractual arrangement between the parties may vary this general rule by allowing the payer to gross-up the amount. ${ }^{43}$

Mostly, withholding taxes are in respect of royalties and dividends. However, in certain jurisdictions, for example Australia, withholding taxes are also imposed on interest payments to non-residents. ${ }^{44}$ Withholding taxes are generally reduced by tax treaties. Thus, residents of a country with a high number of tax treaties may be in a more favourable position as opposed to their counterparts in countries with fewer treaties. As Olivier and Honiball ${ }^{45}$ observe:

"The country of residence of the intermediary headquarter company may have negotiated a more favourable network of tax treaties than the investor country and this may result in the intermediary headquarter company being liable for lower withholding taxes in respect of dividends received. A situation where the relevant intermediary headquarter company jurisdiction does not levy a withholding tax on the payment of dividends will result in an overall reduction in

41 See Arnold and Mclntyre 169. "What is Withholding Tax?" http://www.wisegeek.com/what-iswithholding-tax.htm (accessed 2010-04-13).

42 The most common example of these is in relation to tax on employees where employers are obliged to withhold the tax. Some laws also oblige debtors of sole proprietors to withhold the tax on payment.

43 However, where there is a withholding tax in the country of the person making payment, the parties may agree on a royalty payment that takes into account that there would be tax payable thereon. See Olivier and Honiball 344.

44 In South Africa, secondary tax on companies is payable on declaration of dividends by resident companies. Because this is a tax on the company declaring the dividend, it is not a withholding tax as it is paid by the person who is liable for the tax. The common factor about this type of tax is that the tax incidence is on the shareholder(s). It should be noted that the current tax will be replaced by a new dividend tax which should likely be effective only from the fourth quarter of 2011 , at the earliest. South Africa also levies a withholding tax on royalties at a rate of $12 \%$ of the amount paid. See s 35 .

45 Olivier and Honiball 301. 
tax. This withholding tax advantage is achieved only if the intermediary headquarter company itself is entitled to treaty benefits."

The benefit would arise from the fact that, while trading in the home country, the investor would not have the benefits of the treaties because the home country does not have a treaty with the countries where the ultimate investments are located. By interposing the headquarter company, the investment and other income that arise in the target countries would be collected at the headquarter company host country where they would derive the treaty benefits. Furthermore, it would be desirable for the home and the host countries to have treaties with each other. In this way the income or investments would take the otherwise unavailable treaty route.

As stated above, withholding taxes would be reduced by the use of an IHC. There is, however, a possibility that withholding taxes may be altogether eliminated depending on the content of the treaties ${ }^{46}$ and the participation exemptions available. As typical tax-haven jurisdictions generally do not have good treaty networks, their residents are not likely to benefit from this reduction or elimination of the taxes. An IHC located in such a jurisdiction could be at the disadvantage of not benefiting from the reduction or elimination of taxes.

\section{ACCESSING GROUP TAXATION}

\section{Introduction}

Perhaps one of the main tax reasons why an investor would like to form a headquarter company in a particular country is the fact that the tax systems of certain jurisdictions allow a group of companies to be taxed as one unit, thereby allowing the offset or consolidation of losses or income. This is premised upon the fact that losses in tax are of great use in reducing one's tax liability. Depending on what kind of relief the investor seeks and the countries of the ultimate investments, the investor chooses the location of the headquarter company by also considering this alongside other tax and nontax motivation for the establishment of a headquarter company.

Group taxation is classifiable into three forms: fiscal unity, group contribution or group relief. ${ }^{47}$ These general references can lead to an inaccurate classification, as the terms are often used to refer to group taxation in general as opposed to being used as descriptive of the nature of the particular group taxation system.

Group taxation comprises special rules that are applicable to members of a group of companies under which the group is broadly assimilated for tax

46 This is the case in relation to the treaty between South Africa and the Netherlands in relation to royalties. See Article 12 of the Convention between the Republic of South Africa and the Kingdom of the Netherlands for the Avoidance of Double Taxation and the Prevention of Fiscal Evasion with respect to Taxes on Income and on Capital that entered into force on 28 December 2008.

47 By way of an example, Finland, Norway and Sweden refer to it as group consolidation. The United Kingdom and Ireland refer to it as group relief and Denmark as joint taxation. 
purposes to a single company or entity. ${ }^{48}$ This assimilation is expounded by an adoption of special rules used to offset the losses and profits of companies within a group. These provisions avoid the need to operate as a single legal entity with divisions or branches for tax purposes. In order to further neutralise the taxation within the group of companies, the gain on transfer of capital assets is ignored and only accounted for in the tax system when the assets are transferred to persons who do not form part of that group. ${ }^{49}$ Generally, most countries that apply these provisions allow tax consolidation for resident companies. However, some countries offer worldwide tax consolidation.

\section{Fiscal unity system}

Under this system the company group is treated as a single business entity for tax purposes. The group pools the profits and losses of the group members and files a joint and consolidated tax return. ${ }^{50}$ According to Rohatgi "[g]enerally the losses incurred before the consolidation period by a company are not applied to offset joint profits within the tax group. However, such losses may be carried over by the particular company for offset against its own future profits."

There are variations as to the treatment of gains and losses. For example, the fiscal unity option in Luxembourg does not lead to taxation of the group on its consolidated profits. "Rather, the tax base of each of the members of the fiscal group is calculated separately and includes transactions between members of the fiscal unity, which should be carried on under commercial conditions. Subsequently, the individually computed tax base of each member is added up and taxed at the level of the parent company." ${ }^{.52}$ Owing to the merging of companies' tax liabilities into one, it is rare for non-resident companies to be allowed to participate in this system. ${ }^{53}$

The benefits of a fiscal unity system include: ${ }^{54}$

- A determination of consolidated tax statements on the basis of current rules. In this regard, an application of homogeneous calculation rules favoured by application to all subsidiaries in a group makes group taxation procedures easier and more accurate;

- creation of a system of audits protecting the parent company or organization in relation to joint liability for the fiscal data of the entities included in the consolidation area; and

- a reliable assessment of the tax benefits of including an entity or a number of entities in the consolidation area.

48 IBFD International Tax Glossary definition of "group treatment".

49 Rohatgi Basic International Taxation (2005) 256.

50 Rohatgi 256.

51 Rohatgi 256-257.

52 "Inconsistency of Luxembourg Fiscal Unity Rules with Tax Treaties and EU Law" http://www.ey.com/GLOBAL/content.nsf/Luxembourg_E/Inconsistency_of_Luxembourg_fiscal unity_rules_with_tax_treaties_and_EU_law (accessed 2010-07-08).

53 See further in the "Country Examples" discussion below.

54 http://www.finconsgroup.com/Offers/Proprietary_Solutions/Fiscal_Accounting.kl (accessed 2010-07-02). 


\section{Group-contribution system}

Also referred to as the intra-group contribution system, this system involves the contribution by profit-making companies in the group to one or more lossmaking companies within the same group. ${ }^{55}$ Contributions so transferred are tax-deductible for the paying company and taxable for the receiving companies. Each company files its own tax return and pays its own taxes. Generally, the system requires that both the receiving and paying companies must be resident for tax purposes. ${ }^{56}$

To the extent that the group-contribution system is used to eliminate losses, it has the same economic effect as a group-relief system described below. ${ }^{57}$ The benefit of this system is generally that the profit-making companies reduce their taxable income by transferring some or all of it to loss-making companies. The loss-making companies offset the income against the losses made. Consequently, the tax on the group of companies is reduced.

\section{Group-relief system}

This system is the reverse of the group-contribution system. In the group-relief system a loss-making company surrenders its current losses to the profitable companies in the group. ${ }^{58}$ The transferee company will then be able to utilize the transferred losses to offset against its taxable profits. Each company files its own tax return and pays its own taxes. The surrender of current losses can be done with a subvention payment or without such a payment. A subvention payment is an inter-company payment specifically made for the transfer of company losses for trading or other reasons. ${ }^{59}$

\section{AVOIDANCE OF TAX ON FOREIGN EXCHANGE GAINS AND LOSSES}

\section{Introduction}

Foreign exchange gains and losses arise when a financial obligation arises in a foreign currency, payment is made at a future date and there are currency fluctuations between the time the obligation arose and the time the obligation is discharged. ${ }^{60}$ These gains and losses arise "in connection with assets and liabilities denominated in a currency other than the currency in which a

55 Commission of the European Communities, Communication from the Commission to the Council, The European Parliament and the European Economic and Social Committee, Tax Treatment of Losses in Cross-Border Situations SEC (2006) 7.

56 See Rohatgi 257.

57 See Commission for European Communities 7. See also Äimä and Kiikeri Direct Tax Rules and the EU Fundamental Freedoms: Origin and Scope of the Problem; National and Community Responses and Solutions, Finland, (2006) 5 http://www.fide2006.org/ TOPC1/Tax\%20Kiikeri\%20Finland.pdf (accessed 2010-07-02).

58 See Rohatgi 257. See also Payments for Loss Transfers under the Group Relief System the GST Angle http://www.lawgazette.com.sg/2003-8/Aug03-col.htm (accessed 2010-07-03).

59 IBFD International Tax Glossary definition of "subvention payment".

60 See Olivier and Honiball 575. See also IBFD International Tax Glossary definition of "foreign exchange gain and loss". 
person's accounts are maintained, and are caused by fluctuations in the value of the two currencies relative to each other." ${ }^{\prime 61}$ For example, in a contract of sale a South African buyer agrees to pay a seller US\$100 in twelve months' time and the exchange rate at the time of the conclusion of the contract is US\$ $1=$ ZAR 7. If at the time of payment the rate is US\$ $1=$ ZAR 6 , the cost of the contract for the buyer would have decreased by ZAR 100, in which case the buyer would theoretically have made an exchange gain of ZAR 100. Should the currency take the opposite direction the buyer would have a foreign exchange loss in respect of the sale contract.

\section{Tax treatment of foreign exchange gains and losses}

Different jurisdictions treat foreign exchange gains and losses (hereinafter referred to as "FEGL") differently. ${ }^{62}$ Certain jurisdictions do not tax or allow a deduction for FEGL. Other jurisdictions tax the gains and allow the deduction of the losses. The other option is to tax the gains but not to allow the losses. This option is not popular with taxing jurisdictions.

There are a few other distinctions of treatment of FEGL. ${ }^{63}$ Based on the different treatment in different jurisdictions, a headquarter company can be used to obtain tax benefits where there are foreign exchange losses that reduce the negative tax consequences in relation to foreign exchange gains. Thus, depending on the tax treatment in the investor's residence country and the currency fluctuations, it might be prudent, from a tax point of view, for an investor to move FEGL to a country where the transactional foreign exchange gains and losses will be recognized.

\section{RE-CHARACTERIZATION OF INCOME}

One often finds, in international tax, instances where items of income are treated differently in different jurisdictions. The difference might be in the way one jurisdiction regards certain income derived in that jurisdiction differently from how the other(s) treat the same income. The other version is where

61 IBFD International Tax Glossary definition of "foreign exchange gain and loss".

62 The United Kingdom, New Zealand, Ireland and Canada are examples of countries that foreign exchange gains and allow deductions for losses. Allen and Overy "Where are We Now on Foreign Exchange Gains and Losses" published on website 11 March 2009 http://www.allenovery.com/AOWEB/AreasOfExpertise/Editorial.aspx?contentTypelD=1\&iteml $\mathrm{D}=50601$ \&prefLangl $\mathrm{D}=410$ (accessed 2011-01-31). See Haccius Ireland in International Tax Planning (1995) 546; CCH New Zealand Limited New Zealand Master Tax Guide (2007) 6:213; FBC "Foreign Exchange Losses are Deductible" http://www.fbc.ca/ Keep_Current/Articles/articles02160502.asp (accessed 2010-03-13); and http://www.alleno very.com/AOWEB/AreasOfExpertise/Editorial.aspx?contentTypeID=1\&contentSubTypeID=79 44\&itemID=50601\&prefLangID=410 (accessed 2010-03-13).

$63 \mathrm{Eg}$, the taxation of foreign exchange gains and losses may not necessarily be the same as the underlying transaction, asset or liability. The timing of taxation of foreign exchange gains and losses often differs. The tax treatment may vary for monetary and non-monetary items or depend on the nature of the monetary item. The choice of method may or may not follow the accounting treatment. Certain exchange losses may be "ring-fenced" and only offsettable against the profits from the same business activity. See Rohatgi 536. 
income earned in one jurisdiction is treated in one way, but when it is received by a resident of another jurisdiction, that other jurisdiction treats it differently.

\section{Income paid and received in the same jurisdiction}

A headquarter company can be interposed in a jurisdiction apart from the jurisdiction of the investor where the group companies carry on business operations in order to receive the income arising out of the business operation in the host country. This would arise where, for example, the income earned by a branch in that host country is taxed at a higher rate than resident companies.

This situation arises where the investor has business operations in the host country and intends to utilize a different structure to benefit from the favourable treatment of income arising from the host country and earned by a resident.

\section{Income received from a different jurisdiction}

The different ways in which income is classified often result in income earned in one country being treated differently from how it is treated in the recipient's country. This often occurs where dividends and interest are concerned. However, other instances are where the entities paying (or arguably even receiving) the income are not treated similarly in the different jurisdictions.

In the USA, for example, a Limited Liability Company (hereinafter referred to as "LLC") has three tax options depending on whether it "checks the box" or not. The "check-the-box" system allows the LLC to be taxed variously as a Company, Partnership or S corporation. ${ }^{64}$ When a dividend from such a corporation is declared to a non-resident a mismatch in treatment may arise where it is "checked-the-box" and it is treated as a partnership but the investor country treats it as a company. This might result in higher effective tax rates as the host country would tax the income in the hands of the partner based on source and the investor's country might tax the income as a dividend, with or without the application of a DTA. The converse might result in an avoidance of taxation with the application of a DTA.

64 An S corporation, for United States federal income tax purposes, is a corporation that makes a valid election to be taxed as a company or as a flow-through entity. S-corporation status provides many of the benefits of partnership taxation and at the same time gives the owners limited liability protection from creditors. Generally, an S corporation is exempt from federal income tax other than tax on certain capital gains and passive income. On their tax returns, the S corporation's shareholders include their share of the corporation's separately stated items of income, deduction, loss, and credit, and their share of non-separately stated income or loss. See CCH Editorial Staff Publication, Top Federal Tax Issues for CPE Course (2006); Internal Revenue Service $S$ Corporations www.irs.gov/businesses/ small/article/0, id=98263,00.html (accessed 2010-03-15). For a discussion of the taxation of S corporations see Perez $S$ Corporation Taxation http://taxes.about.com/od/scorporations/ qt/scorp taxation.htm (accessed 2010-03-18). See CCH Editorial Staff Publication US Master Tax Guide (2008) par 301. 


\section{UTILIZATION OF A LIQUIDATION LOSS}

Some tax regimes such as Japan, ${ }^{65}$ the Netherlands ${ }^{66}$ and the United States of America ${ }^{67}$ allow companies to deduct a certain amount of income as a liquidation loss. A liquidation loss occurs where a company liquidates its subsidiary that has realized only losses in its business ventures. ${ }^{68}$ Therefore, where a group decides to venture into a risky business, it may be beneficial from a tax point of view to incorporate a headquarter company in a country where a liquidation loss is allowed to be deducted in the hands of the headquarter company. The headquarter company would then be able to use the loss to set off against the income of other subsidiaries or its own income.

The liquidation loss is normally limited to a certain amount, for example, R100 million. In addition, the local rules may restrict the sale of a headquarter company, or not allow the deductibility of the losses where the headquarter company, or a certain percentage of its shareholding, is sold. ${ }^{69}$ Furthermore, as is the case in the Finnish system, the headquarter company may not be allowed to deduct a loss where it does not carry on active business activities.

\section{CONCLUSION}

While tax is not the main reason why headquarter companies are used, inevitably and increasingly tax considerations play a major role in the decision as to the location of a headquarter company. The tax cost impacts on the general profitability of business enterprises. ${ }^{70}$ The desirable situation is one where the taxes do not tremendously influence (either positively or negatively) the pure business and economic reasons on the setting up and conducting of business activities. Such an endeavour would, in any event, be sabotaged by the high cost of maintaining a headquarter company formed for no business reasons.

Certainly, an enterprise's cash flow and viability could be affected by poor tax planning. This results in tax decisions being part of business planning, as much as marketing strategies, corporate labour policies and management decisions. A distinction should be made between radical tax-planning strategies in terms of which enterprises are set up to take advantage of the tax system and where an investment idea is developed and tuned to take advantage of the available favourable tax regime. The former is tax-driven while the latter is business-driven.

65 See http://ir.capcom.co.jp/english/news/pdf/e081217.pdf (accessed 2009-01-19).

66 See http://www.internationaltaxreview.com/?Page $=10 \& P U B I D=35 \& I S S=12602 \& S I D=47012$ 5\&TYPE=20 (accessed 2010-03-11).

67 See http://www.thefreelibrary.com/Fitch:+U.S.+CMBS+Loss+Severities+Vary,+But+Overall +Continue +To...-a0155655760 (accessed 2010-03-21)

68 Based on a discussion with Mr Serge de Reus, Partner/Director of Corporate International Tax at PricewaterhouseCoopers on 19 September 2008 in Sunninghill, Johannesburg.

69 See Juusela "Finland: Court Decision on Liquidation Loss" (2009) International Tax Review http://www.internationaltaxreview.com/?Page=10\&PUBID=35\&ISS=25471\&SID=722231\&SM $=\&$ SearchStr=\%22holding\%20 company\%22 (accessed 2010-03-21).

70 See Eynatten "European Headquarter Company Tax Regimes: A Comparative Study" 2007 47(12) European Taxation 562-570. 
It is, however, acknowledged that the dividing line gets thinner as specific scenarios are pondered. In the end, investors can use a headquarter company to take advantage of the tax system where its interposition in a certain jurisdiction would result in an overall tax saving for the company group. An example of this is where the headquarter company is formed to trap dividends in a host country which has a DTA with the countries of residence of the operating companies, and where the home country does not have a good treaty network.

There is no doubt that sometimes tax reasons play a role in the decision to form a headquarter company, especially where the tax system in the investor's home country is adverse to the business of the company group. Whether the headquarter company was created for tax reasons or not does not have an impact on its status as a headquarter company. Put differently, the status of a company as a headquarter company is not changed by the fact that it was created to achieve certain tax purposes. It would only be the nature of the headquarter company's activities to change a company from being a headquarter company to one that is not a headquarter company.

As indicated above, where the activities of the headquarter company migrate into the activities of another form of business enterprise, such as an intellectual-property holding company, its tax treatment in the home and host country will reflect the activities of an intellectual-property holding company. This does not detract from the fact that the functions of the headquarter company may be mixed. The tax regime would determine the amount of nonheadquarter company activities that would disqualify the purported headquarter company from functioning as such. Alternatively, the income of the headquarter company could be apportioned in accordance with the volume and nature of its activities.

Investors tend to design their businesses and construct the ideal environment for their investments prior to identifying such an environment. Once the non-tax and tax reasons for setting up a headquarter company have been identified, the next step is to identify a host country with such tax attributes. These relate to the characteristics of the tax regime and legal system, as well as the social and economic environment in the potential host country. It becomes important to consider a jurisdiction based on both the ease with which a headquarter company could be established and the tax characteristics of the host country, as these characteristics would impact on the economic viability of the headquarter company. 